\title{
Hvorfor fortælle dig noget, du allerede ved?
}

\section{Om dufortællinger i dansk litteratur}

Du har sat dig til rette i en blød stol, læseklar. Dufortællinger, siger du højt for dig selv, mens du overvejer, om du nogensinde har læst én - og, dernæst, om du overhovedet ved, hvad en dufortælling er?

Den lidt alternative åbning er et forsøg på at illustrere den desorientering, dufortællinger er i stand til at skabe; på den ene side føler læseren sig tiltalt af det personlige pronomen "du", der i dette tilfælde ovenikøbet indgår i en situation lig hendes egen, og på den anden side ved hun, at du'et umuligt kan være hende - måske ligger hun i en sofa, måske har hun ikke sagt "dufortælling" højt for sig selv. Den særlige form for læserinddragelse, desorienteringen er udtryk for, er imidlertid kun én blandt mange funktioner, duformen kan have. Dansk litteratur rummer et mangfoldigt felt af dufortællinger, hvis historie går tilbage til Johannes V. Jensens eksperimenteren med duformen i kortere passager i romanen Kongens fald (1900-1901). Siden da er flere og flere dufortællinger kommet til: Cecil Bødkers novelle "Trapperne" (1961) og hendes rejseskildring Salthandlerskens hus (1972), Peter Seebergs kortprosatekst "Alzheimer" (1997), Janne Tellers fiktionsessay Hvis der var krig $i$ Norden (2004) og Liv Nimand Duvås roman Rosenreglen (2019) - for blot at nævne et lille udsnit. Fælles for de fem ellers vidt forskellige fortællinger er den samme usædvanlige brug af "du". Modsat dagligdags tale, hvor 1. person, 2. person og 3. person udpeger den eller dem, der taler, tales til og tales om, bliver du'et i dufortællinger ikke tiltalt, hvilket uundgåeligt fører til spørgsmålet: Hvorfor anvende et du, når vedkommende hverken kan høre det eller svare tilbage?

På trods af at dufortællinger er et både udbredt og komplekst fænomen, er der i en dansk sammenhæng stort set ingen forskning på området. Formålet med denne artikel er at sætte fokus på de mange dufortællinger i dansk litteratur og præsentere et perspektiv, der gør det muligt at betragte og behandle en større gruppe af fortællinger som dufortællinger. Ud fra kriteriet om, at du'et bliver refereret til, men ikke tiltalt, foreslår jeg en ny typologi bestående af fire former for dufortællinger, der danner baggrund for min videre undersøgelse af, hvordan brugen af duformen har 
udviklet sig i dansk litteratur. For at belyse en del af de mange funktioner, duformen kan have, foretager jeg til sidst i artiklen to komparative læsninger: Først sammenligner jeg brugen af duformen i Cecil Bødkers novelle "Trapperne" (1961) med brugen af duformen i Amalie Trudsøs tekstsamling Koordinater (2013), som jeg herefter sammenligner med brugen af duformen i en anden nyere tekst, Lone Hørslevs novelle "Saltsprederne" (2017).

\section{En kort fortælling om dufortællinger}

Historisk set har dufortællinger haft en meget lille plads i fortælleteorien. Længe var den udbredte holdning, at de ikke var værd at beskæftige sig nærmere med, og teoretikere fokuserede i stedet på 1.- og 3.-personsfortællinger. Wayne Booth konstaterer i en fodnote om duformen, at "it is astonishing how little difference even this choice makes" (s. 150), mens Gérard Genette omtaler den som "a rare but very simple case" (s. 133). Først i 1990'erne opstod der en egentlig interesse for dufortællinger - her var Monika Fludernik blandt andet redaktør på et særnummer af tidsskriftet Style om netop dufortællinger med bidrag fra toneangivende narratologer som David Herman, Irene Kacandes og James Phelan. Interessen forsvandt dog hurtigt igen, hvilket tematiseres og problematiseres af Rolf Reitan, der i artiklen med den sigende titel "Teorier om dufortællinger: En blindgyde?" (2011) efterlyser "en vej ud af den eksisterende stilstand" (s. 108).

Ifølge Fludernik er hovedårsagen til den utilfredsstillende teoretiske behandling af dufortællinger manglen på en fælles definition. At der optræder et du gør ikke nødvendigvis en tekst til en dufortælling, og det er derfor, som Fludernik understreger, helt afgørende at finde "the golden proportion between 'real' second-person texts and other fiction using the second-person pronoun in interesting and potentially significant ways" (1994, 284). Gennem tiden er forskellige definitioner blevet fremsat; eksempelvis udtaler Helmut Bonheim på et tidligt tidspunkt, at der er tale om en dufortælling, hvis "the 'you' is used over such large stretches of text that the narrative effect is essentially altered" (s. 73-74). En sådan definition medtager potentielt enhver fortælling, der gør brug af “du”, så længe læseren vurderer (og denne vurdering vil, uundgåeligt, være subjektiv), at det har en indvirkning på den narrative effekt. Bonheims definition har på grund af sin bredde mødt en del kritik, og i dag er den udbredte opfattelse da også langt mere specifik: En dufortælling er en fiktionsfortælling, hvor du'et refererer til protagonisten (Prince; Fludernik 1993; Kacandes; DelConte; Richardson).

Selvom Bonheim i sin definition ikke specificerer, hvilken brug af "du" der kendetegner dufortællinger, giver han senere i artiklen en ganske præcis beskrivelse af, hvorfor dufortællinger typisk får læseren til at spærre øjnene op:

6f If one tells a story to a particular person who was on the scene of action himself, the reader will naturally ask himself why the 'you' needs to be told what he must already know. (s. 76) 
Et første bud kunne være at beskrive den usædvanlige pronomenbrug som en form for redundant telling: "the narrator needlessly telling the narratee what she already knows" (Phelan, 11). Trods definitions-uenighederne er der imidlertid bred enighed om, at du'et i dufortællinger netop ikke bliver tiltalt - som Henrik Skov Nielsen i forlængelse af Fludernik og Brian Richardson konstaterer: "The protagonist is referred to and designated, but not addressed by the second person pronoun". ' Faktisk er der, fortsætter Nielsen, intet ud over selve tilstedeværelsen af 2.-personspronomenet "du", der indikerer, at en tiltale finder sted: "He [the you] is just as oblivious to being the centre of a narrative as are the protagonists in third person narratives" (2011a, 12).

Det, der adskiller brugen af "du" i dufortællinger fra dagligdags tale, er altså, at du'et bliver refereret til, men ikke tiltalt, og jeg mener derfor, at det bør udgøre det afgørende kriterie for, om der er tale om en dufortælling eller ej.

\section{Et forslag til en ny typologi}

Hvis vi fastholder kriteriet om reference i stedet for tiltale må den udbredte opfattelse imidlertid revideres. I dansk litteratur findes flere og flere eksempler på fortællinger, der, på trods af at de er kendetegnet ved den usædvanlige pronomenbrug, ikke betragtes som dufortællinger, enten fordi de ikke er fiktive, eller fordi du'et ikke refererer til protagonisten. For at tydeliggøre at sådanne fortællinger også er dufortællinger, foreslår jeg en ny typologi bestående af fire former for dufortællinger:

1) fiktive ekstradiegetiske dufortællinger

2) fiktive intradiegetiske dufortællinger

3) selvbiografiske ekstradiegetiske dufortællinger

4) selvbiografiske intradiegetiske dufortællinger

Typologien er bygget op omkring distinktionerne fiktiv-selvbiografisk og ekstradiegetisk-intradiegetisk og skal ses som et grundlag, den enkelte tekst kan holdes op imod og diskuteres ud fra. Den første distinktion, fiktiv-selvbiografisk, er generisk og gør det muligt at skelne mellem dufortællinger med et overvejende fiktivt indhold og dufortællinger med et overvejende selvbiografisk indhold. Den anden distinktion, ekstradiegetisk-intradiegetisk, beskriver forskellen på fortællinger uden en markeret udsigelsesinstans og fortællinger med en markeret udsigelsesinstans (Genette, 84-85) og gør det muligt at skelne mellem dufortællinger, hvor der kun er et du, og dufortællinger, hvor der både er et jeg og et du. I typologien er den første form identisk med den udbredte opfattelse af, hvad en dufortælling er, nemlig en fiktionsfortælling, hvor du'et refererer til protagonisten, mens de tre andre former falder udenfor på grund af et enten overvejende selvbiografisk indhold eller en 1.-personsprotagonist. I denne artikel vil mit primære fokus være på forholdet mellem ekstradiegetiske og intradiegetiske dufortællinger, og forholdet mellem fiktive og selvbiografiske dufortællinger vil således kun blive berørt i forbindelse med præsentationen af typologien.

Inden jeg forklarer typologien nærmere, er det vigtigt at fastslå, at en udvidelse af feltet ikke er udtryk for en udviskning af den klare distinktion mellem rigtige 
dufortællinger og andre fortællinger, der gør brug af "du". Udvidelsen sker på baggrund af ét kriterie og er altså ikke betinget af arbitrære forhold, såsom hvorvidt 2.-personspronomenet "du" optræder i tilstrækkeligt omfang i en given tekst. Den usædvanlige pronomenbrug, der kendetegner dufortællinger, kan både optræde på et globalt og lokalt niveau: i hele tekster eller i kortere tekstpassager. I udgangspunktet synes betegnelsen "dufortælling" at referere til hele tekster, men ofte er brugen af duformen i kortere tekstpassager mindst lige så interessant. Her bliver effekten om muligt endnu større på grund af de pronominale skift, der tydeligt markerer den bevidste brug af "du"; et oplagt eksempel er Caroline Albertine Minors selvbiografiske novelle "Sorgens have" (2017), ${ }^{2}$ hvor duformen først optræder til allersidst: "Jeg har ikke turdet se den [hjemmevideoen] igen, for der er du, og jeg kan ikke bære det, og jeg vil heller ikke forsøge" (s. 116-117). Gennem hele novellen er ekskæresten, M., blevet omtalt i 3. person, og det uventede skifte til 2. person fungerer da som en påmindelse om den intimitet, parret havde, før han slog hovedet $\mathrm{i}$ en alvorlig ulykke, og forholdet gik i stykker.

Med det slået fast - at duformen kan optræde i både hele tekster og i kortere tekstpassager og være af lige stor interesse og betydning - vil jeg vende tilbage til typologien og de to hovedantagelser, den bryder med: for det første, at dufortællinger nødvendigvis er fiktive, og for det andet, at dufortællinger nødvendigvis har en du-protagonist.

Dufortællinger er hidtil blevet forbundet med fiktionsgenren, hvilket den synonyme anvendelse af betegnelserne second person narrative og second person fiction indikerer (Fludernik 1994; Kacandes; Richardson). Fludernik definerer dufortællinger som "fiction that employs a pronoun of address in reference to a fictional protagonist" (1993, 217, mine kursiveringer), mens Richardson omtaler dufortællinger som "an exclusively and distinctively literary phenomenon" (s. 35), der, i modsætning til 1.- og 3.-personsfortællinger, er uden ikke-fiktivt modstykke. Der er ingen tvivl om, at duformen i kraft af sin usædvanlige pronomenbrug signalerer fiktionalitet, men det er ikke ensbetydende med, at dufortællinger nødvendigvis tilhører fiktionsgenren. Denne antagelse er funderet i Richard Walshs retoriske tilgang til fiktionalitet. I The Rhetoric of Fictionality (2007) gør Walsh op med det dominerende fiktionssyn inden for fiktionsforskningen. En af de mest fremtrædende repræsentanter for dette fiktionssyn er Dorrit Cohn, der i The Distinction of Fiction (1999) skriver: "Fictional narrative is unique in its potential for crafting a self-enclosed universe ruled by formal patterns that are ruled out in all other orders of discourse" (s. vii). Ud fra Cohns separatistiske position er fiktion og ikke-fiktion ontologisk forskellige kategorier, og fiktive fænomener vil derfor aldrig forekomme uden for generisk fiktion. Til forskel fra Cohn skelner Walsh mellem "fiction as a generic category" og "fictionality as a rhetorical resource" (s. 38). Ifølge Walsh er fiktionalitet en retorisk ressource, der ikke er bundet til fiktionsgenren, men kan anvendes i alle former for kommunikation; fiktionalitet kan således optræde lokalt $i$ et værk, uden at det ændrer værkets globale status som ikke-fiktion. I forhold til dufortællinger gør en retorisk tilgang til fiktionalitet det muligt at anskue både fiktive og selvbiografiske værker som dufortællinger, hvis de er kendetegnet ved den samme usædvanlige pronomenbrug. Cecil Bødkers rejseskildring Salthandlerskens 
hus (1972) er et glimrende eksempel på en selvbiografisk dufortælling. I værket beskriver Bødker de tre måneder, hun boede i en etiopisk bjerglandsby, og omtaler konsekvent sig selv i 2. person: "Du er meget langt væk fra alt det som ellers var dit, langt væk i tidsregning, i afstand, i mentalitet - og uden sammenhæng med det du forlod" (s. 35). Det interessante spørgsmål er her, hvilken funktion duformen har i et globalt set ikke-fiktivt værk?

Intradiegetiske dufortællinger adskiller sig fra klassiske dufortællinger ved at have en markeret udsigelsesinstans i form af et jeg, der typisk også er fortællingens protagonist. Ifølge Richardson er dufortællinger blandt andet kendetegnet ved, at det er umuligt at afgøre, om de er homodiegetiske eller heterodiegetiske (s. 28). ${ }^{3}$ Sådan forholder det sig ikke i intradiegetiske dufortællinger, der er entydigt homodiegetiske, da jeg'et er en del af det fortalte univers (Genette, 121). På grund af jeg'et er intradiegetiske dufortællinger typisk lidt mindre bemærkelsesværdige ved første øjekast. Det ændrer dog ikke ved, at pronomenbrugen grundlæggende er lige så usædvanlig som i ekstradiegetiske dufortællinger - heller ikke her bliver du'et tiltalt. Det fremgår klart af følgende passage fra Lone Hørslevs novelle "Lungetræ" (2017), hvor et fraskilt forældrepar besøger deres datter på hospitalet, og faren er frustrereret over, at moren kommer senere end aftalt: "Jeg var på arbejde, sagde jeg. Det var dog utroligt, sagde du og vendte dig rundt og kiggede ud af vinduet" (s. 145). I passagen bliver faren tydeligvis ikke tiltalt; moren beskriver, hvordan han vender sig rundt og kigger ud af vinduet, men beskrivelsen er, i modsætning til den direkte tale "jeg var på arbejde", ikke henvendt til ham.

Betegnelsen "dufortælling" dækker altså over langt flere tekster end tidligere antaget. I det følgende vil jeg med udgangspunkt i typologien skitsere, hvordan duformen har udviklet sig i dansk litteratur siden dens opståen i begyndelsen af 1900-tallet og frem til i dag. Men først vil jeg opholde mig kort ved Fludernik, der med sin diakrone narratologi skaber rammerne for undersøgelser af netop genrer og fortælleformers udvikling over tid.

\section{De danske dufortællinger: et foreløbigt overblik}

I Towards a 'Natural' Narratology (1996) introducerer Fludernik et nyt narratologisk paradigme, der er "explicitly and deliberately historical" (s. xi). Fludernik har, som elev af Franz Stanzel, rødder i den klassiske narratologi, men bevæger sig ud over den ved blandt andet at tage afstand fra dens universalistiske og synkront orienterede bestræbelser; til forskel fra Stanzel og Genette understreger Fludernik, at genrer og fortælleformer forandrer sig over tid og derfor ikke lader sig indpasse i ét begrebsapparat eller én model, der kan bruges på alle tekster til alle tider. Fludernik er inspireret af kognitionsvidenskaben og anvender begrebet "narrativisering" til at beskrive, hvordan læseren på baggrund af allerede etablerede kognitive forståelsesskemaer gør det ukendte forståeligt og læsbart. Narrativiseringsprocessen - "making something a narrative by the sheer act of imposing narrativity on it" (s. 34) - er dels synkron, dels diakron, i den forstand at den på sigt kan resultere i etableringen af nye genrer og fortælleformer: 
6 Once new texts appear on the scene in massive numbers, as has been the case with the novel of internal focalization or with second-person fiction, they may institute a new genre or a new narrative mode. (s. 46)

Med tiden vil nye genrer og fortælleformer blive en integreret del af læserens kognitive forståelsesskemaer, så det, der på et tidspunkt blev opfattet som højst usædvanligt, nu ikke længere gør det i samme grad. Dufortællinger er, ifølge Fludernik, et oplagt eksempel på en fortælleform, der har gennemgået en sådan udvikling:

6f Second-person fiction has recently risen to prominence; it is no longer limited merely to marginal, experimental texts written by unknown authors. Since its early avatars at the beginning of this century second-person narrative has established itself as a highly competitive form, has moved into mainstream literature and is now being used by major authors. (s. 226)

Et tilsvarende billede tegner sig i dansk litteratur: Duformen bliver stadigt mere udbredt og anvendes i dag af en bred skare af forfattere - fra Peter Seeberg (1990; 1997) og Svend Åge Madsen (2006; 2007) til Stine Pilgaard (2012; 2015), Maria Gerhardt (2014; 2017) og Liv Nimand Duvå (2017; 2019). Det er imidlertid værd at bemærke, at brugen af duformen har ændret sig markant siden dens fremkomst i begyndelsen af 1900-tallet til i dag. For at beskrive denne bevægelse foreslår jeg en distinktion mellem eksperimenterende dufortællinger og konventionaliserede ${ }^{4}$ dufortællinger. Distinktionen er tæt forbundet med min typologi - de eksperimenterende dufortællinger er ekstradiegetiske, mens de konventionaliserede dufortællinger er intradiegetiske - men tilfører en historisk dimension, som ikke i udgangspunktet er til stede i typologien.

De eksperimenterende dufortællinger optræder primært i sidste halvdel af 1900-tallet. Duformen dukker imidlertid allerede op i begyndelsen af 1900-tallet, hvor Johannes V. Jensen i en række kortere passager i Kongens fald skifter fra 3. person til 2. person: "Den vældige Evne, du sporede i dig med en Stolthed, som var du den eneste i Verden, den undergraves af Tvivl" (s. 125) og "Det fyger i dit Minde, hvis du tænker; der gaar et isnende Pust af Glemthed over dig. Du hører kun Sneens Fygevise i din vinterlige Erindring" (s. 126). ${ }^{5}$ Cecil Bødkers novelle "Trapperne" udkom i 1961 som en del af novellesamlingen Øjet og er, mig bekendt, den første gennemførte dufortælling i dansk litteratur. Udgivelsesåret er i denne sammenhæng bemærkelsesværdigt, da novellen udkom kun fire år efter Michel Butors roman Valget (orig. La Modification, 1957), der blev kendt som den første dufortælling. ${ }^{6}$ Bødker har med stor sandsynlighed haft kendskab til Butors roman - i hvert fald er det påfaldende, at de to dufortællinger udkom med bare et års mellemrum på det modernistisk-orienterede forlag Arena: den danske oversættelse af La Modification i 1960 og "Trapperne" i 1961. Andre eksempler, der hører under gruppen af eksperimenterende dufortællinger, er Leif Panduros roman Den gale mand (1965) og Thorkild Hansens historiske roman Slavernes kyst (1967). I Den gale mand er omkring en tredjedel skrevet i 2. person, og duformen udgør her en pronominal manifestation af den indre splittelse, protagonisten oplever. I Slavernes kyst tages 
læseren med på rejsen til den afrikanske guldkyst og ser, hvad du'et ser: "Fra bastionerne over porten kan du se langt ind over baglandet" (s. 9). Netop læserinddragelsen er typisk for de eksperimenterende dufortællinger, hvor den manglende udsigelsesinstans resulterer i en desorientering, som uundgåeligt vil få læseren til at stille spørgsmålstegn ved, hvem du'et refererer til. Samtidig fremstår brugen af duformen på grund af læserinddragelsen ofte legende. Begge dele er tydeligt i flere af Seebergs kortprosatekster fra 1990'erne; eksempelvis i "Udviklingen af et rum" (1990), hvor du'et og læseren bliver én i den fælles visualisering af et rum: "Tag to af de fladeste fladheder og sæt dem vinkelret på hinanden, så har du gjort en god begyndelse [...]. Tænk dig om. Du har ingen brug for hammer og søm” (s. 18).

I de seneste 20 år er der sket en konventionalisering af duformen, der optræder langt oftere end førhen og anvendes af bredt læste forfattere som Helle Helle (2000), Pia Juul (2005), Naja Marie Aidt (2006) og Lone Hørslev (2017). Sammenlignet med de eksperimenterende dufortællinger er duformen i de konventionaliserede dufortællinger umiddelbart mindre iøjnefaldende; på grund af den markerede udsigelsesinstans i form af jeg'et er læseren fra begyndelsen bevidst om, at hun træder ind i et fortalt univers, og vil derfor være mindre tilbøjelig til at føle sig direkte tiltalt. Det betyder imidlertid ikke, at brugen af duformen ud fra et analytisk perspektiv er mindre betydningsfuld. Ifølge Brian McHale er "the second person [...] par excellence the sign of relation" (s. 223). Netop relationer spiller en central rolle i flertallet af de konventionaliserede dufortællinger, der typisk behandler emner som parforhold, familieliv og venskaber. I denne forbindelse er der en tendens til, at duformen enten understøtter den intime relation mellem jeg'et og du'et eller i stedet cementerer fraværet af en sådan. I Stine Pilgaards roman Min mor siger (2012) er jeg'et ulykkelig over bruddet med sin ekskæreste, dyrlægen, der omtales i 3. person, men forelsker sig til sidst på ny: "Ved siden af mig ligger du og sover. Jeg prikker dig lige så stille på kinden for at være sikker på, at du findes i virkeligheden. Du slår øjnene op og smiler til mig” (s. 127). Du'et refererer til den nye kæreste, og duformen anvendes derved til at underst $\varnothing$ tte den blomstrende kærlighed mellem de to karakterer. Anderledes forholder det sig i Aidts novelle "Bulbjerg" (2006), hvor jeg'et har været sin kone, Anne, utro. Anne omtales skiftevis i 2. person og 3. person, og duformen vidner her om den dialog, der ikke finder sted i den virkelige verden.

Det er naturligvis ikke muligt at trække en absolut skillelinje mellem eksperimenterende dufortællinger og konventionaliserede dufortællinger; der findes intradiegetiske dufortællinger før årtusindeskiftet og ekstradiegetiske dufortællinger efter årtusindeskiftet. Men bevægelsen er ikke desto mindre klar: I takt med at flere og flere dufortællinger er kommet til, er den intradiegetiske duform blevet mere og mere udbredt. Denne bevægelse er interessant i lyset af Fluderniks narrativiseringsbegreb. På trods af at duformen grundlæggende er den samme i eksperimenterende dufortællinger og konventionaliserede dufortællinger, der begge er kendetegnet ved, at du'et ikke bliver tiltalt, bliver den ofte fuldstændigt overset i sidstnævnte gruppe. I Aidts og Hørslevs novellesamlinger Bavian (2006) og En ordentlig mundfuld (2017) optræder duformen i henholdsvis fem og fire noveller, uden at det bliver omtalt i en eneste anmeldelse. En mulig forklaring er, at den ekstradiegetiske dufortælling med tiden er blevet en integreret del af læserens kogniti- 
ve forståelsesskemaer; læsere er i dag bevidste om duformen som én narrativ teknik blandt andre og lader sig derfor ikke overraske på samme måde som tidligere. De konventionaliserede dufortællinger er i denne sammenhæng netop udtryk for, at både læsere og forfattere har taget duformen til sig, i en sådan grad at den nu anvendes i tekster, der ikke umiddelbart fremstår som udpræget eksperimenterende. Ud fra et analytisk perspektiv er det dog afgørende at holde fast i, at pronomenbrugen er fundamentalt anderledes end i dagligdags tale, og på denne baggrund forholde sig til dens funktion(er) i teksten.

Artiklens omfang tillader ikke en udtømmende kortlægning af duformens mange funktioner, og jeg vil derfor holde mig til tre tekster, hvor duformen anvendes på forskellig vis: Cecil Bødkers novelle “Trapperne” fra 1961, Amalie Trudsøs tekstsamling Koordinater fra 2013 og Lone Hørslevs novelle "Saltsprederne" fra 2017. De tre tekster lægger, som det fremgår af udgivelsesårene, op til både diakron og synkron komparation. Jeg vil således først sammenligne "Trapperne" med Koordinater og derefter Koordinater med "Saltsprederne". Mens "Trapperne" er ekstradiegetisk og tilhører gruppen af eksperimenterende dufortællinger, er Koordinater og "Saltsprederne" begge intradiegetiske og tilhører gruppen af konventionaliserede dufortællinger. I alle tre tekster (og det gælder for enhver dufortælling) er ét spørgsmål centralt: Hvilken betydning har det, at der står "du" i stedet for "jeg", "han" eller "hun"?

\section{Fra det fremmede til det genkendelige}

ff Landskabelig set var der trapper. Landskabelig set var der ikke andet end trapper. Huse og gader og torve af trin. Systemer af trin. Var det mærkeligt? Synes du nogensinde det var mærkeligt, eller undrede det dig slet ikke? (s. 33)

Begyndelsen af Cecil Bødkers novelle "Trapperne" rejser flere spørgsmål, som typisk vil melde sig i ekstradiegetiske dufortællinger: Hvem er du'et? - Er der tale om en fiktiv karakter? Eller måske snarere en læserhenvendelse, selvom det ikke umiddelbart synes at kunne være tilfældet? I "Trapperne" befinder de to karakterer, du'et og forskeren, sig i en verden af trapper. Mens du'et frygter den vilde og ukontrollerbare natur under trapperne, mener forskeren, at den rummer en særlig skønhed. Med tiden bliver du'et mere og mere overbevist om, at forskeren skjuler fundet af en sprække, og beslutter sig til sidst for at slå ham ihjel. Du'ets univers adskiller sig altså fundamentalt fra læserens, og det står derfor hurtigt klart, at du'et ikke er læseren selv. Alligevel vil læseren formodentlig være tilbøjelig til at føle sig tiltalt af det uventede du - særligt første gang, du'et optræder, men også senere i novellen, så snart du'et potentielt kunne referere til læseren: "Fandt du ikke den forhåndenværende verdensordning fortræffelig? Gjorde du ikke? Hvor skulle du også kunne andet? Du havde trapper helt ind i sjælen?" (s. 34). Den kontinuerlige strøm af spørgsmål er umiddelbart rettet mod du'et, men peger samtidig ud af teksten mod læseren, der placeres direkte i du'ets sted og må spørge sig selv: Finder jeg den forhåndenværende verdensordning fortræffelig? Gør jeg? Kan jeg andet? Har jeg trapper helt ind i sjælen? 
Læserinddragelsen er tæt knyttet til de bibelske referencer, fortællingen om du'et og forskeren er vævet hen over. "Alting var fuldkomment" (s. 36), står der om trappeverdenen, der for du'et tager sig ud som et paradis. Dette "paradis" er imidlertid ikke skabt af Gud, men af mennesket selv, hvis behov for orden har manifesteret sig konkret i form af de mange trapper; "de indre livsprincipper" har "bredt sig til landskaberne" (s. 33). Til at begynde med lever du'et en ubekymret tilværelse, overbevist om, at forskeren tager fejl, når han fastholder, at "sprækkerne er der" (s. 36). Men efter kort tid melder tvivlen sig, og du'et oplever en voksende uro, der kulminerer med fundet af en sprække: "Dine øjne begyndte at se, og håret rejste sig dyrisk på huden fordi du blev bange ved at se" (s. 41). Ligheden med Syndefaldsmyten er slående (da Adam og Eva spiste af Kundskabens træ, "åbnedes begges øjne, og de kendte, at de var nøgne" (Bibelen, Gen 3.7)), men forløbet er tvistet; alt det, der også er menneskeligt - det ukontrollerbare, det uforudsigelige, det uskønne - er i du'ets øjne umenneskeligt, og tanken om et sammenbrud af orden er så angstfremkaldende, at der pludselig kun er én mulighed tilbage: Du'et, "den udvalgte" (s. 42), må slå forskeren, slangen i paradis, ihjel. I "Trapperne" er de bibelske referencer, sammen med duformen, med til at tematisere angsten som et menneskeligt grundvilkår. Du'et er således ikke bare en karakter i fortællingen, men enhver læser, ethvert menneske.

Amalie Trudsøs tekstsamling Koordinater udkom mere end 50 år efter "Trapperne", i 2013, og udspiller sig, som undertitlen "Københavnertekster" antyder, til forskel fra den i et genkendeligt univers. De 60 afsnit har alle titler efter gader eller pladser i København og udgør både konkrete og mentale koordinater for jeg'et og hendes møde med byen, som hun er flyttet til for at studere i. Fortællingen spænder over halvandet år, hvor jeg'et på skift forelsker sig i fire du'er. Umiddelbart er duformen mindre iøjnefaldende end i "Trapperne" - dels fordi tekstsamlingen er intradiegetisk, og den markerede udsigelsesinstans i form af jeg'et derfor fra begyndelsen bevirker, at læseren er bevidst om at træde ind i et fortalt univers, dels fordi jeg'et først i tredje afsnit står over for ét af de fire du'er: "Hovedsagelig går jeg vel bare i samlet flok op ad trapperne i opgang nr. 18 og møder dig, som åbenbart bor her og holder den fest, som sender vibrationer ud over hele Vesterbro" (s. 11). Endvidere er læseren på intet tidspunkt i tvivl om, at de fire du'er er karakterer i fortællingen, og tekstsamlingen adskiller sig altså også her fra "Trapperne", hvor læseren, som nævnt, formodentlig vil være tilbøjelig til at føle sig tiltalt ved flere lejligheder. Begge tekster er, på trods af store, både form- og indholdsmæssige, forskelle, kendetegnet ved den samme usædvanlige pronomenbrug - du'et (eller du'erne) bliver ikke tiltalt - men hos Trudsø er duformens funktion i højere grad knyttet til jeg'et og du'erne $i$ teksten end til læseren uden for teksten.

“Jeg vil forære dig alt det skønne, jeg ser. Jeg vil skænke dig København”. Således indledes Koordinater; med et citat af digteren Otto Gelsted, der indfanger fortællingens tre hovedkomponenter: jeg'et, du'et og byen. Helt centralt i tekstsamlingen er det relationelle og spørgsmålet om, hvad det vil sige at opbygge og indgå i en intim relation med et andet menneske. På den ene side er drømmen om at forenes i "et nyt og spinkelt vi" (s. 16), og på den anden side erkendelsen af, at der "indeholdt i tanken om et andet menneske er så mange dele af en selv, at jeg og du opløses i 
hinanden" (s. 50). Jeg'ets syn på de fire du'er forandrer sig i løbet af fortællingen, hvilket blandt andet markeres af de pronominale skift. Kort efter bruddet med det første du møder jeg'et til en koncert det andet du, der først omtales i 3. person: "Man præsenterer mig for en mand, der siger, han er søn af en præst [...]. Kors, han kysser mig” (s. 40-41). I det følgende afsnit har jeg'et lært præstesønnen bedre at kende, og skiftet fra "han" til "du" løfter ham omgående ud af kategorien "tilfældig fremmed": "Jeg vil gynge, siger jeg, nå, siger du” (s. 42). I Koordinater understøtter duformen nærheden mellem jeg'et og de fire du'er, der skiftevis omtales i 2. person og 3. person, afhængig af jeg'ets forhold til den enkelte.

\section{Nærhed og afstand}

Selvom intradiegetiske dufortællinger typisk tematiserer jeg-du-relationen, konnoterer duformen ikke nødvendigvis nærhed. Det fremgår af Lone Hørslevs novelle "Saltsprederne", der udkom kun fire år efter Koordinater, i 2017. Begge tekster foregår i Københavns genkendelige univers og er intradiegetiske; den primære forskel i forhold til fortælleformen er, at der hos Hørslev er ét du, mens der hos Trudsø er fire. I "Saltsprederne" er jeg'et og du'et på vej hjem sammen. De har tilbragt aftenen på Toftegårds Bodega, og jeg'et er igen blevet konfronteret med, at du'et ikke føler det samme for hende, som hun føler for ham: "Jeg forstod at du ikke ville have mig og heller aldrig ville komme til det" (s. 171). I modsætning til Koordinater er der hos Trudsø ingen spirende intimitet mellem jeg'et og du'et. De to karakterer udveksler kun ganske få ord, og novellen er i stedet formet af alt det, der forbliver usagt.

Uf Må jeg sove hos dig, spurgte du. Mine hænder der aldrig rigtig fik hvad de kom efter. Som blev ved med at gribe ud efter dig, men alligevel stadig lå her lige så tomme og hudsultne som altid. Selvfølgelig, sagde jeg. (s. 172)

Det interessante ved passagen er ikke det, der rent faktisk bliver sagt - spørgsmålet "må jeg sove hos dig?" og svaret "selvfølgelig" - men det, der ikke bliver sagt. I det midterste tekststykke fortæller jeg'et om sine forgæves fors $\varnothing g$ på at række ud efter du'et, og brugen af duformen giver umiddelbart indtryk af, at det er henvendt til ham. Du'et kan imidlertid ikke høre det, og "samtalen" i det midterste tekststykke er i bund og grund en konstruktion; for at overkomme afstanden og etablere en form for nærhed mellem sig selv og du'et skaber jeg'et gennem duformen en dialog, som reelt ikke finder sted.

De tre tekster, "Trapperne", Koordinater og "Saltsprederne", er alle kendetegnet ved den samme usædvanlige pronomenbrug: 2.-personspronomenet "du" anvendes om en eller flere karakterer, der hverken kan høre det eller svare tilbage. I alle tilfælde er det centrale spørgsmål, hvilken betydning det har for den samlede forståelse af teksten. Mens du'et i “Trapperne” peger ud mod læseren, der bestandigt placeres i du'ets sted og må forholde sig til strømmen af eksistentielle spørgsmål, spiller læserinddragelse i både Koordinater og "Saltsprederne" en langt mindre rolle, da den markerede udsigelsesinstans i form af jeg'et fra begyndelsen signalerer, at du'et (eller du'erne) er en del af et fortalt univers og ikke læseren selv. Det 
betyder dog ikke, at intradiegetiske dufortællinger aldrig leger med læseren på den måde, der er karakteristisk for ekstradiegetiske dufortællinger; også her vil læseren indimellem kunne føle sig direkte tiltalt. Det er eksempelvis tilfældet i afsnittet "Steenwinkelsvej" i Koordinater, hvor jeg'et forestiller sig, hvilket hus hendes bror ville have boet i, hvis ellers hun havde haft én: "Lige derovre - dér, ser du? i det hus, der har en forhave. Det er dig, jeg taler til. Det er os to, der går tur i dag, bare så du ved det" (s. 48). En sådan form for læserinddragelse er dog mere undtagelsen end reglen; for det meste er duformens funktion i intradiegetiske dufortællinger knyttet til relationen mellem jeg'et og du'et $i$ teksten frem for læseren $u d e n$ for teksten.

\section{Perspektiver}

Du strækker dig et øjeblik, inden du igen lader dig falde tilbage i den bløde stol. Du mangler kun et enkelt afsnit nu, og du har - forhåbentlig - fået en langt bedre idé om, hvad en dufortælling er.

I artiklen har jeg argumenteret for nødvendigheden af en bredere og mere nuanceret forståelse af dufortællinger og foreslået en ny typologi, der omfatter enhver fortælling - fiktiv såvel som selvbiografisk, ekstradiegetisk såvel som intradiegetisk - hvor du'et bliver refereret til, men ikke tiltalt.

Artiklen åbner således op for læsninger af tekster, der ikke tidligere er blevet betragtet og behandlet som dufortællinger. Mit fokus har hovedsagelig været på forholdet mellem ekstradiegetiske og intradiegetiske dufortællinger, men forholdet mellem fiktive og selvbiografiske dufortællinger er mindst lige så interessant. Med en retorisk tilgang til fiktionalitet bliver det muligt at undersøge brug af duformen uden for fiktion: i selvbiografiske værker som Cecil Bødkers Salthandlerskens hus (1972), men potentielt også i reklamer og politiske kampagner. Et andet perspektiv, der rækker ud over denne artikel, vedrører tekster, der, fordi de ikke uden videre lader sig placere i typologien, kan være med til at belyse forholdet mellem duform og lignende litterære teknikker; eksempelvis Naja Marie Aidts selvbiografiske værk Har døden taget noget fra dig så giv det tilbage. Carls bog (2017), hvor du-omtalen af forfatterens afdøde søn, Carl, hverken kan betegnes som duform eller apostrofe.

Artiklen er første skridt mod en kortlægning af en righoldig, men overset, del af dansk litteraturhistorie. Duformen optræder i dag i et utal af sammenhænge og har, som læsningerne af "Trapperne", Koordinater og "Saltsprederne" illustrerer, ikke bare én, men mange funktioner, der i alle tilfælde viser sig afgørende for forståelsen af den pågældende tekst.

\section{Noter}

I Fludernik definerer dufortællinger som "fiction that employs a pronoun of address in reference to a fictional protagonist" (1993, 217), mens dufortællinger ifølge Richardson er "any narration other than an apostrophe that designates its protagonist by a second person pronoun" (s. 19).

2 "Sorgens have" indgår i novellesamlingen Velsignelser, men indholdet er ifølge Minor selv overvejende selvbiografisk: Både virkelighedens og tekstens Caroline oplevede en stor sorg, da ekskæresten kom ud for en ulykke og mistede hukommelsen (se Egebo; Moestrup; Wittrock). 
3 Der har tidligere været stor uenighed om, hvorvidt dufortællinger er homodiegetiske eller heterodiegetiske. Franz Stanzel mener, at "the 'you' is really a self-dramatization of the 'I"' (s. 225), mens dufortællinger ifølge Genette er "a variant of heterodiegetic narrating” (s. 133).

4 Betegnelsen "konventionaliserede dufortællinger" er inspireret af Nielsen, der i tråd med Fludernik skriver: "When new techniques or modes of telling are invented they often appear strange at first, but then - if they are succesful - become conventionalized and cease to appear strange" (2011b, 86, min kursivering).

5 Om brugen af "du" i Kongens fald foreslår Stefan Iversen betegnelsen "manende apostrofe", der i lighed med duformen i klassiske ekstradiegetiske dufortællinger "rejser tvivl hos læseren om, hvem der taler, og hvem der tales til" (s. 270).

6 Valget er, som Richardson gør opmærksom på, ikke den første dufortælling. Alligevel omtales Butor ofte som opfinderen af duformen som narrativ teknik (s. 20).

\section{Litteratur}

Aidt, Naja Marie (2006): "Bulbjerg", "Konference”, "Slik", "Store træers grønne mørke” og "Torben og Maria”, i Bavian, København: Gyldendal.

Bibelen (1992): Bibelen, København: Det Danske Bibelselskab.

Bonheim, Helmut (1983): "Narration in the Second Person", i Recherches Anglaises et Américaines 16, s. 69-80.

Booth, Wayne (1983): The Rhetoric of Fiction, Chicago: The University of Chicago Press.

Butor, Michel ( 1960): Valget, København: Arena.

Bødker, Cecil (1961): “Trapperne”, i Øjet, København: Arena.

Bødker, Cecil (1972): Salthandlerskens hus, København: Gyldendal.

Cohn, Dorrit (1999): The Distinction of Fiction, Baltimore: The Johns Hopkins University Press.

DelConte, Matt (2003): “Why You Can't Speak: Second-Person Narration, Voice, and a New Model for Understanding Narrative", i Style 37.2, s. 204-219.

Duvå, Liv Nimand (2017): Vi er vel helte, København: Forlaget Kronstork.

Duvå, Liv Nimand (2019): Rosenreglen, København: Gyldendal.

Egebo, Karen Sofie (2017): "Ung forfatter: I sorgen kan mødet med en fremmed være en velsignelse", i Kristeligt Dagblad, 24. marts 2017.

Fludernik, Monika (1993): "Second Person Fiction: Narrative You As Addressee And/Or Protagonist", i Arbeiten aus Anglistik und Amerikanistik 18.2, s. 217-247.

Fludernik, Monika (1994): "Introduction: Second-Person Narrative and Related Issues”, i Style 28.3, s. 281-311.

Fludernik, Monika (1996): Towards a 'Natural' Narratology, London og New York: Routledge. Genette, Gérard (1988): Narrative Discourse Revisited, Ithaca: Cornell University Press.

Gerhardt, Maria (2014): Der bor Hollywoodstjerner på vejen, København: People’s Press.

Gerhardt, Maria (2017): Transfervindue, København: Politikens Forlag.

Hansen, Thorkild (1967): Slavernes kyst, København: Gyldendal.

Helle, Helle (2000): “Jeg kører frem”, i Biler og dyr, København: Samleren.

Hørslev, Lone (2017): “Fugleklatten”, “Indien”, "Lungetræ” og “Saltsprederne”, i En ordentlig mundfuld, København: Rosinante.

Iversen, Stefan (2018): Den uhyggelige fortælling: unaturlig narratologi og Johannes V. Jensens tidlige forfatterskab, Aarhus: Aarhus Universitetsforlag. 
Jensen, Johannes V. (1900-1901): Kongens fald, København: Gyldendal.

Juul, Pia (2005): "Elly Byde”, i Dengang med hunden, København: Tiderne Skifter.

Kacandes, Irene (1994): “Narrative Apostrophe: Reading, Rhetoric, Resistance in Michel Butor's La Modification and Julio Cortazar's 'Graffiti”, i Style 28.3, s. 329-349.

Madsen, Svend Åge (2006): Det syvende bånd, København: Gyldendal.

Madsen, Svend Åge (2007): "Manden der opdagede at han ikke eksisterende", i Manden der opdagede at han ikke eksisterende, København: Gyldendal.

McHale, Brian (1987): Postmodernist Fiction, New York og London: Methuen.

Moestrup, Mathilde (2017): “Man ved jo godt, at folk kan dø, men ikke hvordan det er, når de ikke længere kan genkende en”', i Information, 22. april 2017.

Minor, Caroline Albertine (2017): “Sorgens have”, i Velsignelser, København: Rosinante.

Nielsen, Henrik Skov (2011a): “Fictional Voices? Strange Voices? Unnatural Voices?”, i Per Krogh Hansen, Stefan Iversen, Henrik Skov Nielsen og Rolf Reitan (red.): Strange Voices in Narrative Fiction, Berlin: De Gruyter, s. 55-81.

Nielsen, Henrik Skov (2011b): "Unnatural Narratology, Impersonal Voices, Real Authors, and NonCommunicative Narration", i Jan Alber og Rüdiger Heinze (red.): Unnatural Narratives - Unnatural Narratology, Berlin: De Gruyter, s. 71-88.

Panduro, Leif (1965): Den gale mand, København: Gyldendal.

Phelan, James (2004): Living to Tell about it: A Rhetoric and Ethics of Character Narration, Ithaca, NY: Cornell University Press.

Pilgaard, Stine (2012): Min mor siger, København: Samleren.

Pilgaard, Stine (2015): Lejlighedssange, København: Samleren.

Prince, Gerald (1987): A Dictionary of Narratology, Lincoln: University of Nebraska Press.

Reitan, Rolf (2011): “Teorier om dufortællinger: En blindgyde?”, i Kultur \& Klasse 112, s. 107-132.

Richardson, Brian (2006): “At First You Feel a Bit Lost. The Varieties of Second Person Narration”, i Unnatural Voices: Extreme Narration in Modern and Contemporary Fiction, Columbus: Ohio State University Press, s. 17-36.

Seeberg, Peter (1990): "Udviklingen af et rum”, i Rejsen til Ribe, København: Gyldendal.

Seeberg, Peter (1997): “Alzheimer”, i Halvdelen af natten, København: Gyldendal.

Stanzel, Franz (1984): A Theory of Narrative, Cambridge: Cambridge University Press.

Teller, Janne (2004): Hvis der var krig i Norden, Frederiksberg: Dansklærerforeningens Forlag.

Trudsø, Amalie (2013): Koordinater, København: Rosinante.

Walsh, Richard (2007): The Rhetoric of Fictionality. Narrative Theory and the Idea of Fiction, Columbus: Ohio State University Press.

Wittrock, Sebastian (2017): "Forfatteren Caroline Albertine Minor: 'Det var vigtigt for mig at kunne skrive om et religiøst rum fra et begyndersted”, i Politiken, 8. November 2017. 